\title{
Thy-1 is expressed in myofibroblasts but not found in hepatic stellate cells following liver injury
}

\author{
Jozsef Dudas • Tümen Mansuroglu • Danko Batusic • \\ Giuliano Ramadori
}

Accepted: 31 August 2008 / Published online: 17 September 2008

(C) The Author(s) 2008. This article is published with open access at Springerlink.com

\begin{abstract}
Thy-1 (CD90) is an adhesion molecule induced in fibroblast populations associated with wound healing and fibrosis. In this study the question whether Thy-1-geneexpression can be induced in hepatic stellate cells (HSC) in vivo, under conditions of liver injury or liver regeneration was addressed. Acute and chronic rat liver injury was induced by the administration of $\mathrm{CCl}_{4}$. For comparison, cirrhotic human liver, and rat $67 \%$ partial hepatectomy $(\mathrm{PH})$ was studied as well. Thy-1-gene-expression was examined also in isolated human liver myofibroblasts. Thy-1-mRNA expression was significantly upregulated in chronic liver injury. Thy $-1^{+}$cells were detected in the periportal area of rat liver specimens in normal-, injured- and regenerativeconditions. In chronic human and rat liver injury, Thy- $1^{+}$ cells were located predominantly in scar tissue. In the pericentral necrotic zone after $\mathrm{CCl}_{4}$-treatment, no induction of Thy-1 was found. Gremlin and Thy- 1 showed comparable localization in the periportal areas. Thy-1 was not detected in either normal or capillarized sinusoids, in isolated rat HSC, and was neither inducible by inflammatory cytokines in isolated HSC, nor upregulated in treated myofibroblasts. Based upon these data Thy-1 is not a marker of "activated" sinusoidal HSC, but it is a marker of "activated" (myo)fibroblasts found in portal areas and in scar tissue.
\end{abstract}

Electronic supplementary material The online version of this article (doi:10.1007/s00418-008-0503-y) contains supplementary material, which is available to authorized users.

J. Dudas · T. Mansuroglu · D. Batusic $\cdot$ G. Ramadori $(\square)$

Department of Internal Medicine,

Section of Gastroenterology and Endocrinology,

Georg-August-University Göttingen,

Robert-Koch-Strasse 40, 37075 Göttingen, Germany

e-mail: gramado@med.uni-goettingen.de
Keywords Hepatic stellate cells · Rho-GTP-ases . Myofibroblasts invasivity · GPI-anchored proteins . Lipid raft

\section{Introduction}

Several fibroblastic cell types have been described in the liver (Johnson et al. 1992). Typical hepatic stellate cells (HSC), transitional cells [intermediate between HSC and myofibroblasts (MF)] and MF have been reported to be present in the perisinusoidal space of Disse. Portal tracts are reported to harbor portal (myo)fibroblasts. In addition, periductal (myo)fibroblasts and vascular smooth muscle cells residing in the walls of portal vein branches and portal arteries have been thought to constitute distinct subpopulations of mesenchymal cells in the portal tract (Cassiman and Roskams 2002). Another subpopulation of liver fibroblastic cells are the MF located around the centrolobular vein: the so-called second-layer cells (Cassiman and Roskams 2002). These second-layer cells were suggested to proliferate in the livers of alcohol-fed baboons, causing typical 'alcoholic type' pericentral fibrosis (Nakano and Lieber 1982). Finally, (myo)fibroblasts residing in the liver capsule (Glisson's capsule) form a potential source of extracellular matrix in the liver (Cassiman and Roskams 2002; Ramadori and Saile 2004; Blanc et al. 2005; Guyot et al. 2006).

Hepatic stellate cells (HSC) (Ito cells, lipocytes) are the pericytes of the liver sinusoid (Anonymus 1996; Cassiman et al. 2002; Ramadori ans Saile 2004). Their main physiological function is vitamin A (retinoid) storage (Ramadori et al. 1990; Cassiman and Roskams 2002; Ramadori and Saile 2002). In liver injury HSC (of the liver sinusoids) transform from a quiescent to an "activated" state (Ramadori 
et al. 1990; Cassiman et al. 2002; Ramadori and Saile 2002). HSC were identified in tissue sections by detection of the intermediate filament protein Desmin (Johnson et al. 1992).

Myofibroblasts (MF) have been reported as being absent from normal liver, and produced as a result of activation of precursor cells like portal fibroblasts (Guyot et al. 2006). Studies have shown that non-parenchymal cells express $\alpha$-smooth muscle actin (SMA), similar to that of myofibroblasts in healing wounds in fibrotic rat and human liver (Johnson et al. 1992; Guyot et al. 2006). These cells are morphologically similar to Desmin-positive HSC. The precise relationship between these various cell populations has not been fully determined (Johnson et al. 1992).

Identification of the different mesenchymal cells in the damaged liver by means of the in vitro determined phenotypical and functional markers, and of their quantitative contribution to the development of liver fibrosis has been difficult (Ramadori and Saile 2002). The differentiation of the "activated" hepatic stellate cells from myofibroblasts is only possible through their localization within the hepatic lobule. However, in some locations, as for example the sinusoids several subpopulations of liver mesenchymal cells may be present under various conditions. A commonly used phenotypic marker, SMA, is expressed in activated hepatic stellate cells, in liver myofibroblasts (MF) and in smooth muscle cells of the portal and the central vessels (Knittel et al. 1999a; Cassiman and Roskams 2002; Ramadori and Saile 2004). In contrast, Fibulin-2 and Gremlin (Ogawa et al. 2007) have been described as specific markers for MF, and differentiates them from "activated" HSC (aHSC). However, as secreted proteins (Ogawa et al. 2007), they can confirm the identification of myofibroblasts in vitro, but less clearly in vivo (Knittel et al. 1999a). In fact, in vitro studies have shown that, Fibulin-2- or Gremlin-synthesis is absent in HSC, but it is present in MF populations. Furthermore, in vitro studies have classified SMA/ Fibulin-2/IL-6 positive cells as MF (Knittel et al. 1999a; Ramadori and Saile 2002; Saile et al. 2002). Functional in vitro studies suggest that cultured rat HSC and MF differ not only in expressing different markers, but also in expressing different cytokines and growth factors (Schirmacher et al. 1992; Tiggelman et al. 1995; Knittel et al. 1999a), as well as their different responses to various cytokines and growth factors (Tiggelman et al. 1995; Saile et al. 2002 , 2004. Moreover, they also differ in apoptotic and proliferation characteristics, and in cell cycle regulation (Saile et al. 2002, 2004; Dudas et al. 2003; Ogawa et al. 2007). Although, several functional differences have been described in liver mesenchymal cells in vitro, in lack of reliable identification marker of those cells in vivo, it was difficult the coupling of the in vitro data with the in vivo models and with the human cirrhosis.
In 2006 the cell surface glycoprotein: Thy-1 was identified as a specific marker of liver myofibroblasts (Mansuroglu et al. 2006). Thy-1 is a glycophosphatidylinositol (GPI)-linked outer membrane leaflet glycoprotein, which belongs to a subset of haematopoetic stem cell markers. It was first described in 1964, and subsequently isolated, purified, and characterized in rodents (Reif and Allen 1964). Koumas et al. (2003) reported that human fibroblasts are heterogeneous with respect to cell surface Thy- 1 expression and that fibroblasts could be segregated into Thy $-1^{+}$and Thy $1^{-}$subsets resulting with distinct functions.

Recent gene expression analysis of isolated liver cell populations in our laboratory has demonstrated that significant Thy-1 expression can be recognized in cultured rat liver myofibroblasts (SMA-and Fibulin-2-positive). In contrast, Thy-1-gene-expression is not found in freshly isolated, or in qHSC or aHSC. At the levels of mRNA and protein subcultured rat liver myofibroblasts represented one homogenous Thy-1-positive cell population, similar to that of myofibroblasts in other tissues (Dudas et al. 2007). Based on these data, Thy- 1 expression might be a cell surface marker capable of distinguishing HSC and hepatic myofibroblasts populations in vivo.

In a previous study it was reported that Thy- 1 expression is induced in fibroblast populations associated with wound healing and fibrosis (Pei et al. 2004). In the present study the question whether Thy-1-gene-expression becomes detectable in hepatic stellate cells (HSC) in vivo, under conditions of liver injury or liver regeneration was addressed utilizing $\mathrm{CCl}_{4}$-induced rat liver injury and regeneration, or partial hepatectomy of the rat liver, and examination of human liver cirrhosis. In all three models the expression of alpha smooth muscle actin was detectable in "activated HSC" of the liver sinusoids. In addition the gene expression of established markers of liver myofibroblasts (SMA, Fibulin-2, Gremlin) (Knittel et al. 1999a; Ogawa et al. 2007) was compared to that of Thy- 1 .

\section{Materials and methods}

\section{Materials}

All chemicals were purchased from Merck (Darmstadt, Germany), Applichem (Darmstadt, Germany) or Sigma (Steinheim, Germany). The materials utilized for biochemical and immunohistochemical procedures are listed in the appropriate sections.

\section{Liver specimens}

One histologically normal and two cirrhotic liver specimens were received from the Department of Gastroenteropathology 
(Georg-August-University Göttingen, Germany). Informed consent was obtained from each patient included in the study and the study protocol confirmed to the ethical guidelines of the 1975 Declaration of Helsinki as reflected in a priori approval by the institution's human local ethics committee. Three-human liver samples were used for immunohistochemical analysis.

\section{Animals}

Wistar rats were purchased from Harlan Winkelmann (Borchen, Germany), and received humane care in compliance with the institutions' and the National Institutes of Health guidelines.

\section{Animal models}

The following rat models were used for examination of rat liver damage, and regeneration: $\mathrm{CCl}_{4}$-induced acute liver injury (by a single $\mathrm{CCl}_{4}$-administration) and chronic liver injury with regeneration (after sequentially repeated $\mathrm{CCl}_{4}$ administration up to 17 weeks). In addition rat liver after partial hepatectomy $(\mathrm{PH})$ was utilized as an example of regenerating liver. Sham operations were performed in the controls of the PH-treated animals (Dudas et al. 2006).

Male and female Wistar rats weighing approximately $200 \mathrm{~g}$ were given $\mathrm{CCl}_{4} /$ corn oil solution $(50 \%$, v/v) orally as described earlier (Dudas et al. 2006). Acute liver damage was induced by administration of a single dose of $150 \mu \mathrm{l} \mathrm{CCl}_{4} / 100 \mathrm{~g}$ body weight; control animals were given corn oil only (Neubauer et al. 1998). Each two animals were sacrificed $3,6,9,12,24,48$ and $72 \mathrm{~h}$ after treatment. The liver was removed, and snap-frozen in liquid nitrogen. For the induction of liver fibrosis, chronic damage and regeneration: animals (male and female Wistar rats weighing approximately $200 \mathrm{~g}$, were exposed to oral application of $\mathrm{CCl}_{4}$ once a week for a period of 1217 weeks. At the end of the treatment, the liver was removed and snap-frozen in liquid nitrogen. The frozen specimens were used for RNA isolation and immunohistochemical studies.

Isolation of rat HSC, rat liver myofibroblasts, human liver myofibroblasts and culture conditions

Hepatic stellate cells and liver myofibroblasts were isolated by sequential in situ perfusion with collagenase and pronase as described previously (Knittel et al. 1999a; Neubauer et al. 1996). Yields of $40 \times 10^{6} \mathrm{HSC}$ in mean were obtained per rat. Purity was $>85 \%$ in freshly isolated cells. Cells were plated at a density of 30,000 cells $/ \mathrm{cm}^{2}$ and cultured in Dulbecco's modified Eagle's medium (DMEM, PAA, Linz, Austria) supplemented with $15 \%$ fetal calf serum (FCS), $100 \mathrm{U} / \mathrm{ml}$ penicillin, $100 \mu \mathrm{g} / \mathrm{ml}$ streptomycin and $1 \%$ L-glutamine. The culture medium was replaced 2 days after plating and then every second day. The cultured cells were maintained at $37^{\circ} \mathrm{C}$ in a $5 \% \mathrm{CO}_{2}$ atmosphere with $100 \%$ humidity.

Rat liver myofibroblasts were isolated as described previously (Novosyadlyy et al. 2004; Dudas et al. 2007). Human liver myofibroblasts were isolated as described recently by Müller et al. (2007). The rat and human liver myofibroblasts were cultured as described above.

Immunostaining of cryosections and isolated liver cells

Five-micrometers thick sections were prepared with a cryostat (Reichert Jung, Wetzlar, Germany) for each model and for human liver samples. For the immuncytochemical analyses, human hepatic myofibroblasts were cultured on chambered slides (Nunc, Roskilde Denmark). Sections were air-dried, chambered slides were washed with $1 \times$ PBS (Biochrom, Berlin, Germany) and used for immunohistoor cyto-chemical studies with 10 minutes of acetone fixation at room temperature. After blocking with $1 \%$ bovine serum albumin (Serva, Heidelberg, Germany) and 10\% goat serum (DAKO, Glostrup, Denmark) in PBS (Biochrom) for $1 \mathrm{~h}$ at room temperature, two primary antibodies were added simultaneously, or one primary antibody was incubated on the sections, overnight at $4{ }^{\circ} \mathrm{C}$. The primary antibodies used were: rabbit polyclonal: anti-Desmin (1:100, Acris Antibodies, Hiddenhausen, Germany) anti-Gremlin (1:200, Imgenex, San Diego, CA, USA) rabbit monoclonal: anti-SMA (1:100, Epitomics, Burlingame, CA, USA); mouse monoclonal: anti-Desmin (1:100; DAKO), anti-ratThy-1 (1:50; Clone: OX-7, Pharmingen, San Diego, CA, USA), anti-human-Thy-1 (1:50; Pharmingen) and antiSMA (Sigma, Steinheim, Germany) (1:37.5, Upstate, Lake Placid, NY, USA). Rabbit mono- and poly-clonal antibodies were realized with Alexa 555-conjugated goat-anti-rabbit secondary antibody (Molecular Probes, Leiden, the Netherlands), diluted 1:400 in PBS. Mouse monoclonal antibodies were visualized with Alexa 488- or Alexa 555conjugated secondary goat-anti-mouse antibody (Molecular Probes) diluted 1:200 in PBS. The immunostained sections were examined with fluorescent microscopy after counterstaining with DAPI (Molecular Probes). The stainings were analyzed with an epifluorescent microscope (Axiovert 200M, with Apotome function) (Zeiss, Jena, Germany). The microphotographs were obtained using the Axiovision 4.2 and 4.5 softwares of Zeiss.

Negative control immunostainings were performed, both by omission of the primary antibody and usage of isotypespecific control immunoglobulins, as well as usage of antibodies directed against antigens not expressed in rat liver (Dudas et al. 2006, 2007). 
Quantitation of Thy-1-positive cells

Quantitation of Thy-1-positive cells detected by immunohistochemistry was performed by counting of positive cells (positive-stained particles) in ten independent fields on sections of normal rat liver and of different time points after acute and chronic $\mathrm{CCl}_{4}$-induced rat liver injury. The analysis of positive reaction was performed by the application of the Image J software (Wayne Rasband, NH, USA). The average and standard deviation of the counted positive particles were displayed graphically, and were also analyzed related to the counted particles in the control rat liver. The quantitation of Thy- $1^{+}$immunohistochemical reaction was correlated with the Thy-1 mRNA expression by correlation analysis (Graphpad Prism software).

\section{RNA isolation and real-time RT-PCR}

Total RNA was isolated after homogenization in guanidinium-isothiocyanate (Invitrogen, Carlsbad, CA, USA) from isolated cells after culture and from livers of normal, acute and chronic $\mathrm{CCl}_{4}$-treated, sham-operated or partial hepatectomized rats, followed by $\mathrm{CsCl}$ (Invitrogen) gradient ultra-centrifugation (Chirgwin et al. 1979). Reverse transcription of RNA samples was performed with MMLV reverse transcriptase (Invitrogen), according to the instructions of the manufacturer. Real-time PCR analysis of reverse transcripts (cDNAs) was performed with the Abi Prism Sequence Detection System 7000 of Applied Biosystems (Foster City, CA, USA) following the manufacturer's instructions, using Sybr-green reaction master mix (Invitrogen) and primers described in previous studies (Gremlin (Ogawa et al. 2007), SMA (Dudas et al. 2007), or in Table 1. Primers were synthesized by MWG Biotech (Ebersberg, Germany) or by Invitrogen. The quantity of the PCR products of the genes of interest was determined based on the threshold PCR cycle-values ( $C_{\mathrm{t}}$ value), following the instructions of Applied Biosystems and normalized relative the quantities of the endogenous control (Ubiquitin C) PCR product (Raddatz et al. 2005). Ubiquitin $C$ expression was not affected by any of the treatments used in the animal models. The normalized Thy-1, Fibulin2, Desmin, Gremlin and SMA PCR-product quantities of treated animals were compared to the values of control animals, and the relative expression was plotted against the observation time (Dudas et al. 2006, 2007). In all cases, two or more animal series were analyzed in duplicates. Statistical significance $(P<0.05)$ was tested with Student's t-test, and One-way Analysis of Variance (ANOVA).

\section{Results}

Thy-1 in normal rat liver

In normal rat liver, sparse periportal Thy-1-expression was detected adjacent to the wall of the portal vein, arteries, and bile ducts. No specific Thy-1-reaction was detected within the hepatic parenchyma (Dudas et al. 2007).

Thy $-1^{+}$cells were located within the stroma of portal tracts found adjacent to the wall of the portal vein, and of the hepatic artery. Thy- $1^{+}$cells typically showed a periportal localization (Fig. 1a). SMA was present in smooth muscle cells of the media of portal tract vessels (Dudas et al. 2007), and in cells lining the hepatic vein radicles (Johnson et al. 1992). Gremlin located in the wall of portal arteries and within the stroma of portal tracts. Thy-1 directly did not co-localize with Gremlin, rather the two markers showed adjacent localization in the portal tract (Fig. 1a).

In the normal rat liver: Thy-1, Gremlin and Fibulin-2 mRNA expression was low, while SMA and Desmin expression was higher.

Thy-1 in $\mathrm{CCl}_{4}$-induced acute and chronic liver injury

Utilizing the $\mathrm{CCl}_{4}$ model characterized by pericentral hepatocellular necrosis, inflammation, and regeneration resulting in a complete restitution, the distribution of Thy-1 relative to the other markers was analyzed. Livers obtained from $\mathrm{CCl}_{4}$-treated animals were studied from 3 to $72 \mathrm{~h}$ following the administration of the $\mathrm{CCl}_{4}$.

Table 1 Primers used for quantitative real-time RT-PCR

\begin{tabular}{|c|c|c|c|c|}
\hline Gene & Forward primer & Reverse primer & $\begin{array}{l}\text { Amplicon } \\
\text { length (bp) }\end{array}$ & $\begin{array}{l}\text { mRNA } \\
\text { location }\end{array}$ \\
\hline Rat Thy-1 & 5'-TGA ACC CAG TCA TCA GCA T-3' & 5'-CAG TCG AAG GTT CTG GTT CAC C-3' & 106 & $47-153$ \\
\hline Rat Fibulin-2 & 5'-AGT CTG CCC AGG TAT CTC CCA A-3' & 5'-TCG CCA ATA ACG CGA CAC A-3' & 102 & $2237-2339$ \\
\hline Rat Ubiquitin $\mathrm{C}$ & 5'-CAC CAA GAA GGT CAA ACA GGA A-3' & 5'-AAG ACA CCT CCC CAT CAA ACC-3' & 101 & $2379-2480$ \\
\hline Rat Desmin & 5'-GTG AAG ATG GCC TTG GAT GT-3' & 5'-CGG GTC TCA ATG GTC TTG AT-3' & 182 & $1248-1430$ \\
\hline Rat Gremlin & 5'-GAT TGG TGC AAA ACT CAG CCC-3' & 5'-AAG GAG TTG CAC TGG CCG TAA-3' & 101 & $413-514$ \\
\hline Human Thy-1 & 5'-CTA GTG GAC CAG AGC CTT CG-3' & 5'-TGG AGT GCA CAC GTG TAG GT-3' & 236 & $141-376$ \\
\hline
\end{tabular}




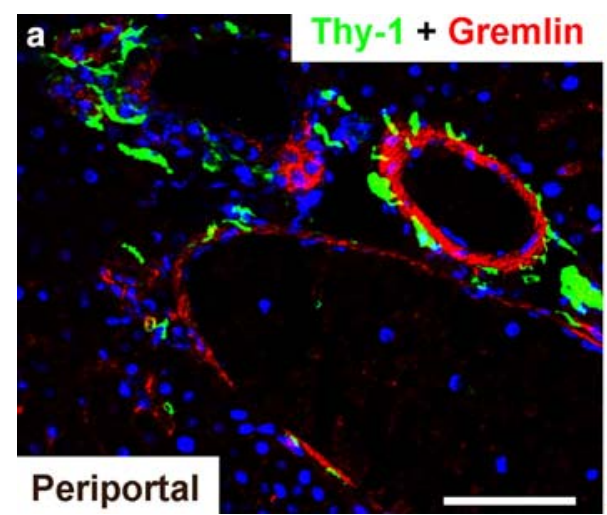

Fig. 1 Thy-1 and Gremlin detection in normal rat liver, Thy- 1 and SMA in human liver. Immunofluorescent staining of Thy-1 (green) (a, b) and Gremlin (a) (red) or SMA (b) in sections of the normal rat (a) and human (b) liver. Arrows represent periportal co-localization

In livers with acute $\mathrm{CCl}_{4}$-induced liver injury the mRNA expression of Thy-1, Desmin and SMA was increased significantly after $48 \mathrm{~h}(P<0.01$, with one-way ANOVA, Fig. 2a). Thy-1 was increased $1.85 \pm 0.04$-fold while SMA: $11.95 \pm 3.02$-fold (Supplementary Table S1). The increase of Desmin was $2.69 \pm 0.87$-fold. The Fibulin-2and Gremlin-gene expression did not change over time (Fig. 2a).

In the chronic $\mathrm{CCl}_{4}$-treated rats Thy-1-, SMA-, DesminGremlin- and Fibulin-2 expression increased significantly in comparison to that of control animals (Student's $t$ test, $P<0.01$, Supplementary Table S1).

In the $\mathrm{CCl}_{4}$ injury model Thy- $1^{+}$cells were detectable within the cell-rich stroma adjacent to the walls of periportal arteries and veins (Fig. 3a). The $\mathrm{SMA}^{+}$cells were present in the vessel walls of portal areas, several of them expressing also Thy-1. Forty-eight hours after $\mathrm{CCl}_{4}$-treatment the number of Thy- $1^{+}$cells increased (Fig. 3a, b), and the positive cells still remained within the portal areas. In this location in more cells Thy-1 co-localized with SMA (Fig. 3 a, arrows). These cells were identified as Thy- $1^{+}$ fibroblasts (Fig. 3a).

After repeated $\mathrm{CCl}_{4}$-administration the Thy- $1^{+}$reaction remained primarily in the periportal area, similar to that of SMA, being localized within the fibrotic septa (Fig. 3a). A diffuse $\mathrm{SMA}^{+}$reaction was found in the sinusoids of the regenerating nodules. The $\mathrm{SMA}^{+}$-reaction did not show significant sinusoidal co-localization with Thy-1 (Fig. 3a).

Similarly to the mRNA expression, the Thy-1-immunhistochemical reaction increased at later time points after $\mathrm{CCl}_{4}$-administration, and in chronic rat liver injury (Fig. 3b). The immunohistochemical changes correlated well with the gene expression data (the correlation coefficient was 0.94, Supplementary Table S1).

Since Thy- 1 has been identified on the endothelium of newly formed blood vessels (Lee et al. 1998), the immuno-

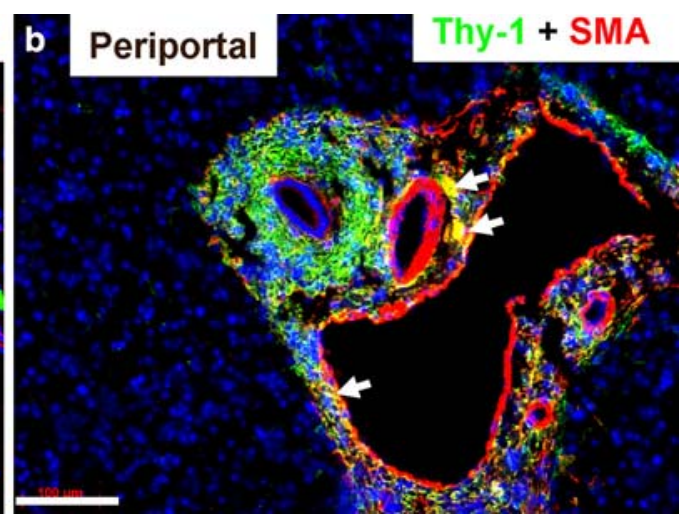

between Thy- 1 and SMA in the normal human liver. $\mathbf{a} \times 200 ; \mathbf{b} \times 100$ original magnification. The blue staining with DAPI represents the nuclei. a Bar $50 \mu \mathrm{m}$. b Bar $100 \mu \mathrm{m}$

histochemical localization of Thy-1 with that of von Willebrand-factor (vWF) was examined (Fig. 4). Thy-1 was expressed only in the periportal areas, and was not found in the acinar zone 3 after acute liver damage. In contrast, vWF labeled the central vein, and manifested a spot-like reaction in acinar zone $348 \mathrm{~h}$ after $\mathrm{CCl}_{4}$ administration, but no Thy$1^{+}$reaction was detected in this zone (Fig. 4b). Co-localization of Thy- 1 and vWF was limited, therefore with Thy- $1^{+}$ expression seen only adjacent to the walls of $\mathrm{vWF}^{+}$vessels in both acute and chronic liver injury due to $\mathrm{CCl}_{4}$.

The immunolocalization of Thy-1 was compared with a recently described marker of liver myofibroblasts: Gremlin. Gremlin was found in the wall of the central vein, and it colocalized with Thy- 1 in rare microvessels (Fig. 5). Thy- $1^{+}$ cells were identified in the periportal areas next to the Gremlin $^{+}$cells. In chronic liver injury, Thy- 1 and Gremlin were found in the fibrotic septa and the regenerating nodules. In the fibrotic septa co-localization of these two markers was demonstrated.

Thy-1 in the rat partial hepatectomy liver regeneration model

In regenerating rat liver [after partial hepatectomy $(\mathrm{PH})$, Thy-1, Fibulin-2 and Gremlin gene expression did not increase $(P>0.05$, one-way ANOVA, Fig. 2b, Supplementary Table S1). SMA- and Desmin-gene-expression significantly increased 8-24 h after PH $(P<0.05$, with one-way ANOVA) (Fig. 2b). After Sham operation, no upregulation of the genes investigated was observed (Fig. 2b).

Several hours to several days after partial hepatectomy (PH), Thy-1 showed a periportal localization similar to that seen in the normal liver. Thy $-1^{+}$cells were found adjacent to the portal vessels, and co-localized with SMA or Desmin (Fig. 6a, b). A fine-structured $\mathrm{SMA}^{+}$immunohistochemical reaction was demonstrated perisinusoidally in the liver 
Fig. 2 Analysis of Thy-1-geneexpression in comparison with known markers of liver mesenchymal cells in $\mathrm{CCl}_{4}$-induced acute rat liver injury and in partial hepatectomy induced liver regeneration. a Thy-1, Fibulin-2, Desmin, Gremlin and SMA relative expressions in livers of single $\mathrm{CCl}_{4}$-treated rats, at indicated time points after treatment, related to corn oil-treated controls. The graphs plotted represent two independent treatment series, in duplicates. Asterisks represent significant upregulation, at level of $P<0.05$. The expression levels of the treated rats were compared with controls using oneway ANOVA. b SMA, Desmin, Thy-1, Fibulin-2 and Gremlin relative expressions in livers of partial hepatectomised rats, at indicated time points after $\mathrm{PH}$, related to Sham-operated rats. The graphs plotted represent two independent treatment series, in duplicates. Asterisks: significant upregulation, at level of

$P<0.05$. The expression levels of the treated rats were compared with controls using Student's $t$ test

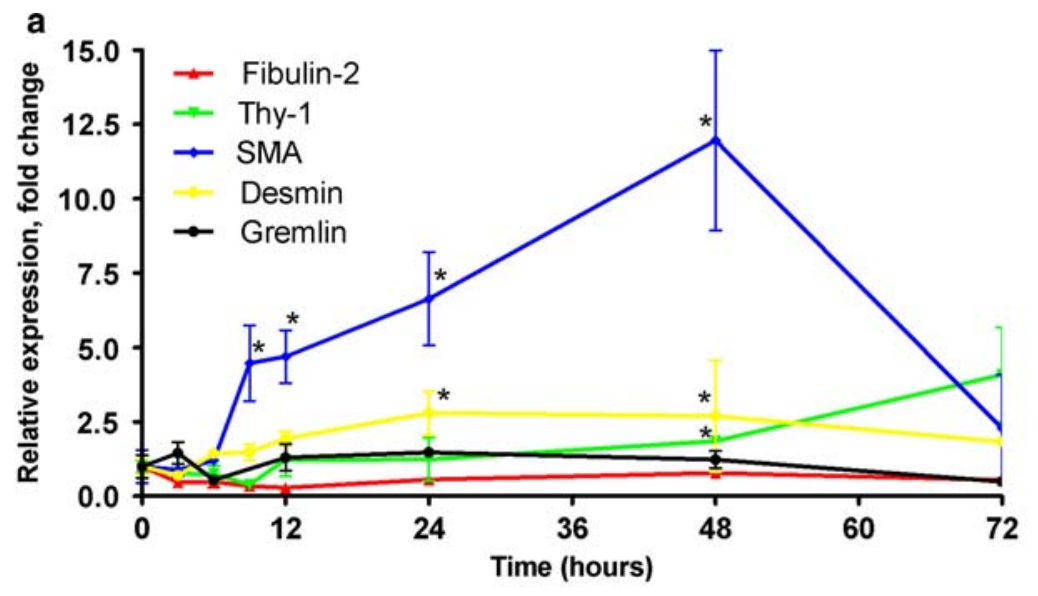

b

SMA
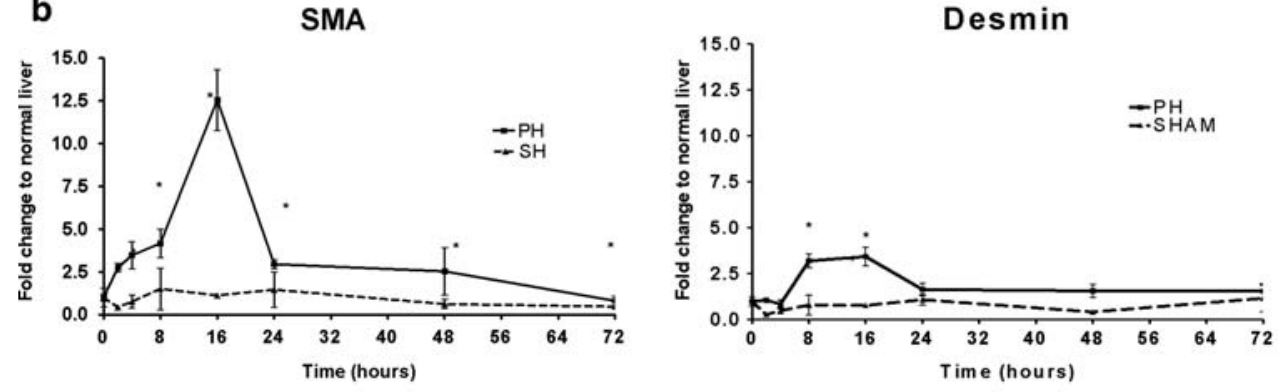

Thy-1

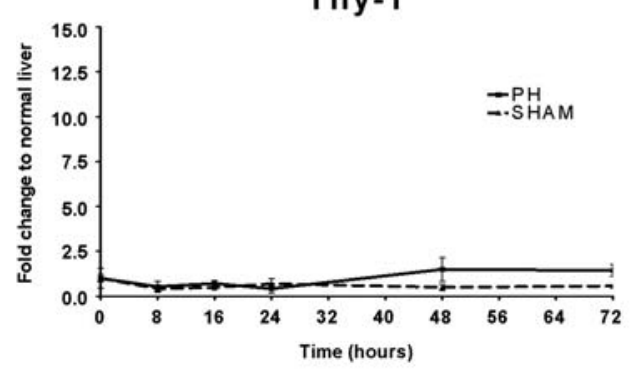

Fibulin-2

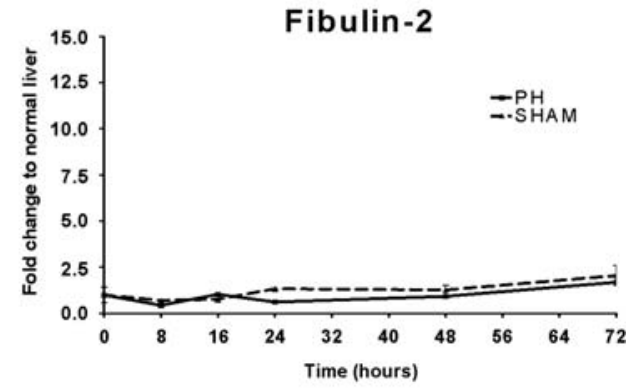

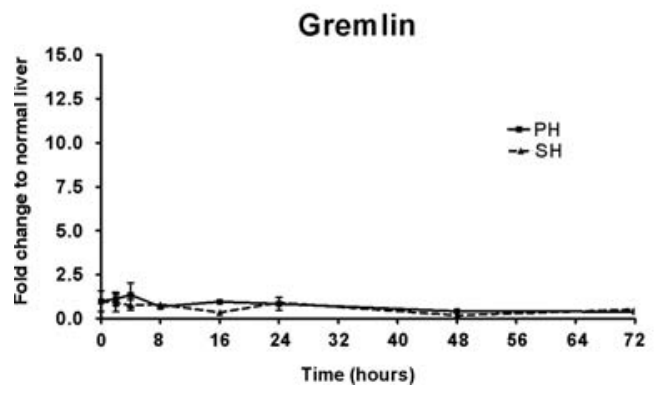

parenchyma $16 \mathrm{~h}$ after PH (Fig. 6b). Forty-eight hours after $\mathrm{PH}$ the $\mathrm{SMA}^{+}$reaction was reduced significantly, following the mRNA expression-pattern (Figs. 2b, 6b,).

Desmin showed positive reaction in the stromal cells of the periportal area, in the wall of the central vein and in the liver sinusoids. The sinusoidal reaction increased 16-24 h after $\mathrm{PH}$, and after $48 \mathrm{~h}$ it was reduced to normal level. Thy-1 co-localized with Desmin in the stromal cells of the periportal areas and in the wall of the portal vessels at each time points studied after $\mathrm{PH}$. The Thy- $1^{+}$sinusoidal reaction was diffuse, and it did not co-localize with Desmin (Fig. 6).

Thy-1 in the normal human liver and human cirrhosis

In normal human liver Thy- $1^{+}$cells were located within the periportal tract, and were more numerous than in the rat liver (Fig. 1b). This finding was confirmed by real-time RT-PCR. 
a
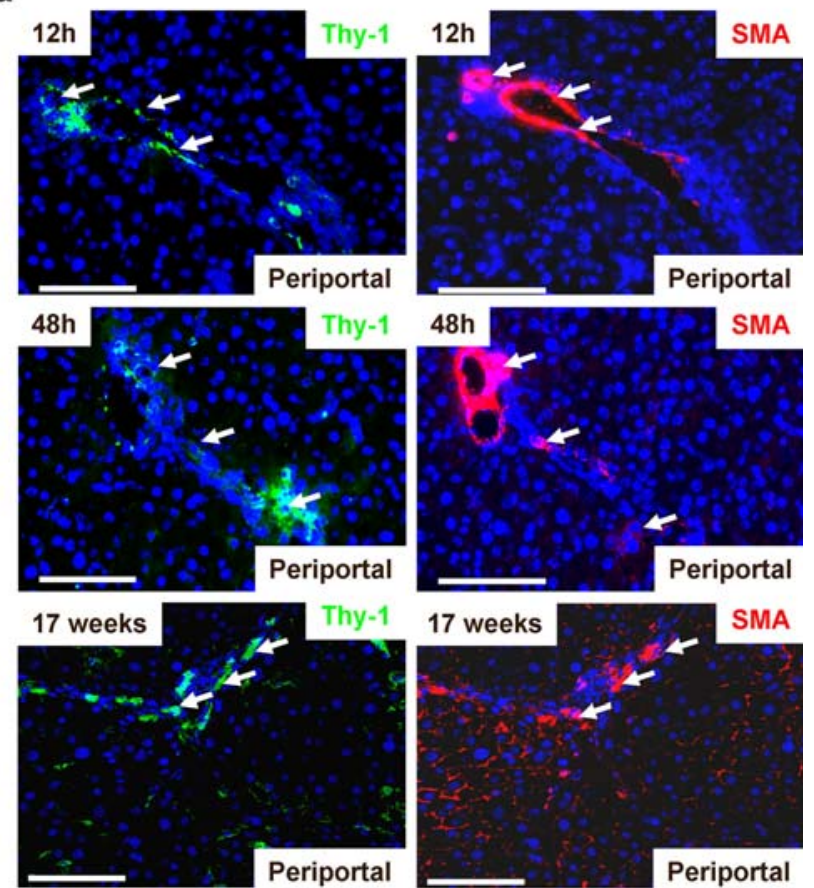

b

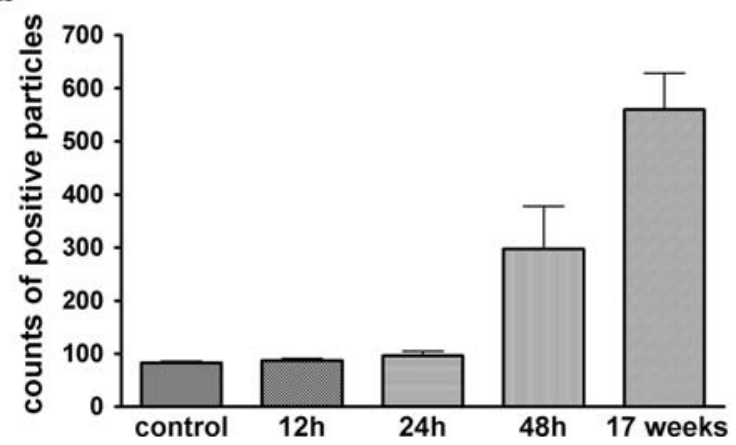

Fig. 3 Immunolocalization of Thy- 1 and $\mathrm{SMA}$ in $\mathrm{CCl}_{4}$-induced acute and chronic rat liver injury. Immunofluorescent stainings of Thy-1 (green) and SMA (red) after acute liver injury (12, $48 \mathrm{~h})$ (a) induced by a single administration of $\mathrm{CCl}_{4}$ and after chronic rat liver injury after 17 weeks of treatment (induced by weekly repeated administrations of $\mathrm{CCl}_{4}(\mathbf{a})$. The Thy-1 and SMA immunofluorescent labelings were compared on sequential sections. Periportal co-localizations are indicated by arrows. The blue staining with DAPI represents the nuclei ( $\times 100$ original magnification, bars $100 \mu \mathrm{m}$ ). Quantitative analysis of Thy-1 immunohistochemical reaction (positively stained particles) in acute and chronic rat liver injury due to $\mathrm{CCl}_{4}$-administration (b)

The average $C_{\mathrm{t}}$ value (threshold cycle value) of Thy- 1 in the normal rat liver was 31.05 , while in the normal (non-cirrhotic) human liver it was 29.8. The immunohistochemical reaction of Thy-1 co-localized with SMA in the periportal area (Fig. 1b). In human cirrhosis Thy-1-gene-expression increased as compared to the normal human liver. Thy $-1^{+}$ cells were predominantly located in the cirrhotic septa, and they appeared to be invading the regenerating nodules (Fig. 7). Thy-1 co-localized in more cells with SMA and Desmin within the scar tissue of the cirrhotic septa (Fig. 7a, a

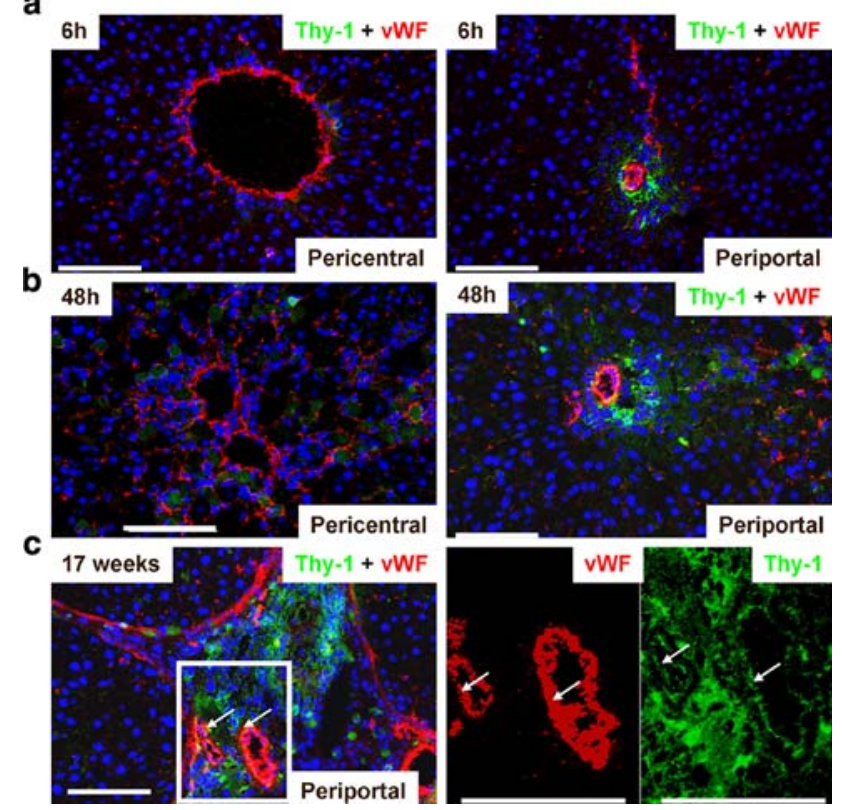

Fig. 4 Immunolocalization of Thy-1 and vWF in $\mathrm{CCl}_{4}$-induced acute and chronic liver injury. Immunofluorescent stainings of Thy-1 (green) and $\mathrm{vWF}(\mathrm{red})$ after acute liver injury [6 $\mathrm{h}(\mathbf{a}), 48 \mathrm{~h}(\mathbf{b})$ after a single administration of $\left.\mathrm{CCl}_{4}\right]$, in the pericentral area (left panels) and in the periportal area (right panels). Immunofluorescent stainings of Thy-1 (green) and vWF (red) after chronic rat liver injury [17 weeks after weekly repeated administrations of $\left.\mathrm{CCl}_{4}(\mathbf{c})\right]$. Co-localization of the two markers was labeled by arrows and shown magnified in the right panel. The blue staining with DAPI represents the nuclei $(\times 200$ original magnification, bars $100 \mu \mathrm{m}$ )

$\mathrm{b}$, arrows). In the scar tissue and adjacent to the septa Thy-1 rarely co-localized with von Willebrand-factor (vWF) (Fig. 7a, b). In the sinusoids adjacent to the scar tissue rare scattered co-localization between Lyve-1 and Thy-1 was detected (Fig. 7c). Von Willebrand-factor and Lyve-1 are endothelial markers (Mouta Carreira et al. 2001). Both Desmin and SMA labeled Thy-1 ${ }^{-}$sinusoidal cells (Fig. 7a).

Thy-1 expression in human liver myofibroblasts

Rat liver myofibroblasts showed a homogeneous Thy $-1^{+}$ population, which we reported previously (Mansuroglu et al. 2006; Dudas et al. 2007). As is the case with isolated rat liver myofibroblasts, isolated human liver myofibroblasts are $\mathrm{Thy}-1^{+} / \mathrm{SMA}^{+}$, but only minimally express Desmin (Fig. 8).

\section{Discussion}

Multiple investigations have reported (Ogawa et al. 2007) that the conventional qHSC-enriched fraction contains two types of cells, true qHSCs as the major cell type and a minor fraction of MFs (Table 2). The former cells lack 


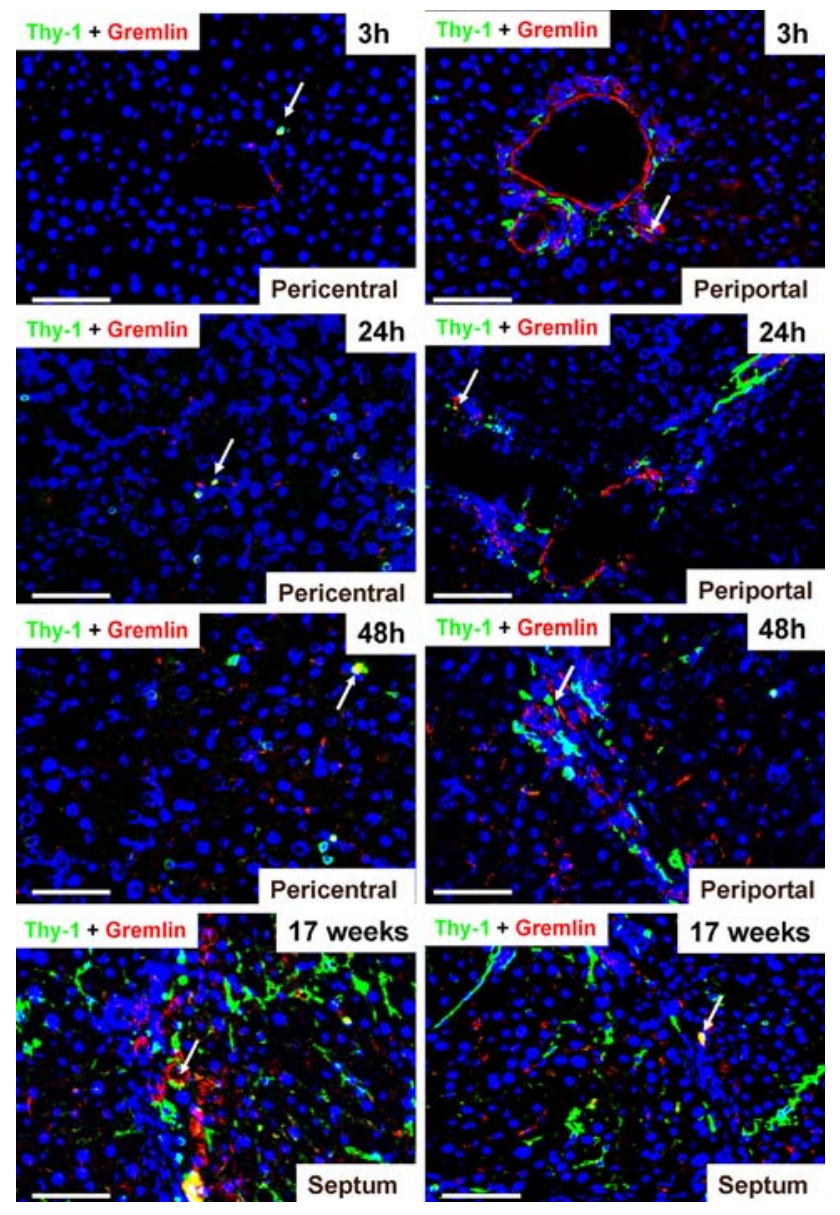

Fig. 5 Immunolocalization of Thy-1 and Gremlin in $\mathrm{CCl}_{4}$-induced acute and chronic liver injury. Immunofluorescent stainings of Thy-1 (green) and Gremlin (red) after acute and chronic liver injury at indicated time points after administration of $\mathrm{CCl}_{4}$, in the pericentral area (left panels) and in the periportal area (right panels). On the lower panels septal areas of cirrhotic livers ( 17 weeks after repeated treatment) were represented. Co-localization of the two markers was labeled by arrows. The blue staining with DAPI represents the nuclei $(\times 200$ original magnification, bars $100 \mu \mathrm{m}$ )

growth ability and spontaneously undergo activation (induction of SMA expression) and, as recently described, to terminal differentiation characterized by expression of a large panel of late vascular smooth muscle cell markers (Wirz et al. 2008) and manifested by the spontaneous Fasmediated apoptosis (Saile et al. 2002). Importantly, these same investigators have (Ogawa et al. 2007; Saile et al. 2002; Dudas et al. 2003), clearly demonstrated that the minor cell population, MFs, but not aHSCs, have replicative activity (Table 2). At 7 days in culture aHSC expressed Desmin, P100, and Alpha-2-Macroglobulin, MF expressed Fibulin-2, but not P100, and Alpha-2 Macroglobulin (Knittel et al. 1999a; Ogawa et al. 2007, Table 2).

In this study it was analyzed if Thy-1 was induced in activated (SMA expressing) hepatic stellate cells within the liver sinusoid. The experiments were performed to test the hypothesis as to whether in vivo induction of SMA-geneexpression, which is considered as a marker of activation is always accompanied by induction of Thy-1-gene-expression also in hepatic stellate cells, which is considered as a population of (myo)fibroblastic cells.

HSC are mainly present in the hepatic parenchyma and at the scar-parenchymal interface. MFs are the principal cells located within the scar tissue (Knittel et al. 1999b). Thy-1 expression has the potential to distinguish between aHSC and rMF in vitro (Mansuroglu et al. 2006; Dudas et al. 2007). In the current study we found that Thy-1-geneexpression is not induced in hepatic stellate cells lining the liver sinusoids in vivo, which are in response to liver injury and partial hepatectomy become SMA-positive (Table 2). In addition, in human cirrhosis Thy- $1^{+}$cells are enriched in the cirrhotic septa, especially in the scar tissue, and invade the regenerating nodules. Both in humans and rats, Thy $-1^{+}$ cells are typically portal stromal cells. The present in vitro results demonstrate that, Thy- $1^{+}$cells represent populations of portal fibroblasts and myofibroblasts, both in the human and rat (Dudas et al. 2007). Expression of Thy-1 in endothelial cells was detected in the border of the scar tissue of the advanced human cirrhosis (Fig. 7). Thy-1 expression in endothelial cells was rare. In our previous studies (Dudas et al. 2007) utilizing northern blot-analysis, western blotanalysis and immunocytochemistry, Thy-1-expression could not be demonstrated in freshly isolated, or in cultureactivated HSC. In contrast, in vitro experiments proved at mRNA and at protein levels that subcultured liver myofibroblasts represent a homogenous, uniform Thy $1^{+}$cell population. This finding in isolated rat liver cells has been confirmed in isolated and subcultured human liver myofibroblasts (Fig. 8). Sensitive methods utilizing real-time RT-PCR and flow cytometry detected Thy-1-expression, but showed at least 20-times lower representation in HSC than in rat liver myofibroblasts. This finding might be due to a contaminating population of MF, identified by flow cytometry (Dudas et al. 2007), but low-level expression of Thy-1 in HSC can not be excluded (see Fig. 7c). TGF $\beta 1$, IL- $1 \beta$ or TNF $\alpha$ cytokines do not induce Thy-1-expression in HSC (data not shown). The same cytokines did not increase Thy-1-gene-expression in MF.

In chronic rat liver injury the increased periportal expression of Thy-1-reaction was associated with increased expression of SMA and Gremlin (Supplementary Table $\mathrm{S} 1$ ). In acute rat liver injury Thy-1 could not be demonstrated in perisinusoidal cells. In this model of rat liver injury local upregulation of inflammatory cytokines (including IL- $1 \beta$, TNF- $\alpha$ and IFN- $\gamma$ can be demonstrated 6-24 $\mathrm{h}$ after the $\mathrm{CCl}_{4}$ administration (Sheikh et al. 2006), while no sinusoidal Thy- $1^{+}$staining was observed. This means that, inflammatory cytokines with the potential to induce Thy-1 expression (demonstrated in endothelial cells 
Fig. 6 Thy-1, Desmin and SMA in PH-induced rat liver regeneration. a Immunofluorescent labelings of Thy-1 (green) and Desmin (red) in rat liver 4, 8,24 and 48 h after $\mathrm{PH}$, analyzed in the pericentral (left panels) and periportal spaces (right pan$e l s)$. Periportally, Desmin partly co-localised with Thy-1, while Thy-1 was only sparsely present in the pericentral area. In the pericentral sinusoids the Desmin ${ }^{+}$ reaction was not accompanied by Thy-1. Arrows: co-localization of Thy-1 and Desmin. The blue staining with DAPI represents the nuclei, $\times 200$ original magnification, bars $100 \mu \mathrm{m}$. b Immunofluorescent staining of Thy-1 (green) and SMA (red) in rat liver $4-48 \mathrm{~h}$ after $\mathrm{PH}$. Thy-1 was found mainly periportally, while SMA showed also a perisinusoidal localization $(\times 200$ original magnification). The blue staining with DAPI represents the nuclei, bars $100 \mu \mathrm{m}$, Arrows co-localization of Thy-1 and SMA

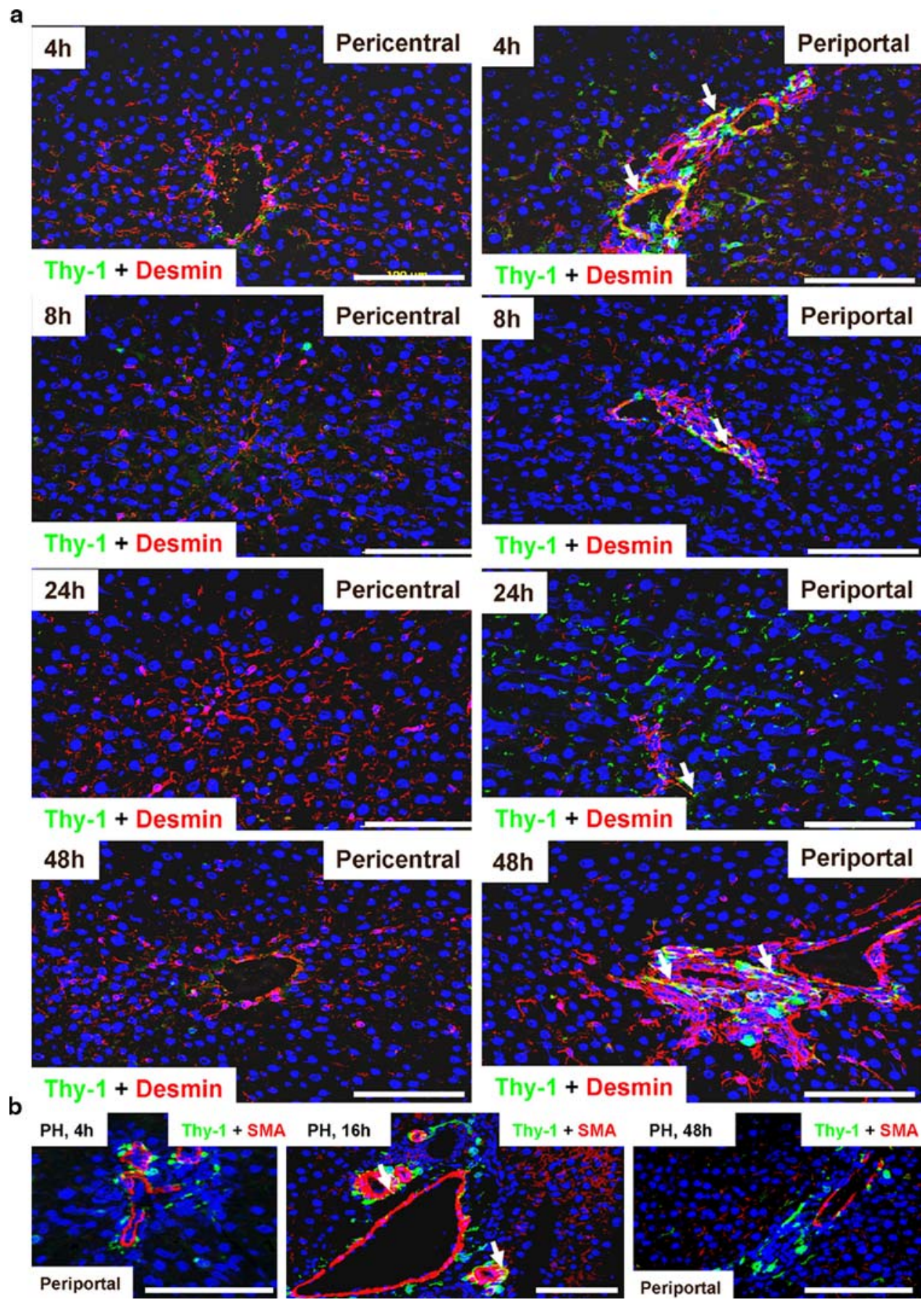

by Mason et al. 1996) do not do so in hepatic stellate cells. Moreover, in vitro stimulation of 5 different isolations of HSC with TNF- $\alpha$ both in the quiescent and activated stages, did not lead to induction of Thy-1-gene-expression (data not shown). In advanced stages of liver fibrogenesis: moderate Thy-1- Gremlin- and SMA- positivity can be found in the portal sinusoids (Figs. 3, 5). Interestingly, Thy $-1^{+}$and $\mathrm{SMA}^{+}\left(\mathrm{Gremlin}^{+}\right)$reactions were separated, apart from scattered dual immunoreactivity.
After PH, Thy-1 expression is present principally in periportal localization. However, Thy- $1^{+}$cells can be also found in the sinusoids, adjacent to the portal tract at $24 \mathrm{~h}$ after $\mathrm{PH}$ (Fig. 6). Similarly to the findings of acute $\mathrm{CCl}_{4}$-induced liver injury, Thy $-1^{+}$cells are not present in the pericentral areas. After $24 \mathrm{~h}$ of PH, SMA-gene-expression decreases (Figs. 2, 6), probably as a result of apoptosis of HSC (Saile et al. 1997). The pattern of Thy-1 and SMA expression in rat liver sinusoids $16-48 \mathrm{~h}$ after $\mathrm{PH}$ is different. SMA has a 

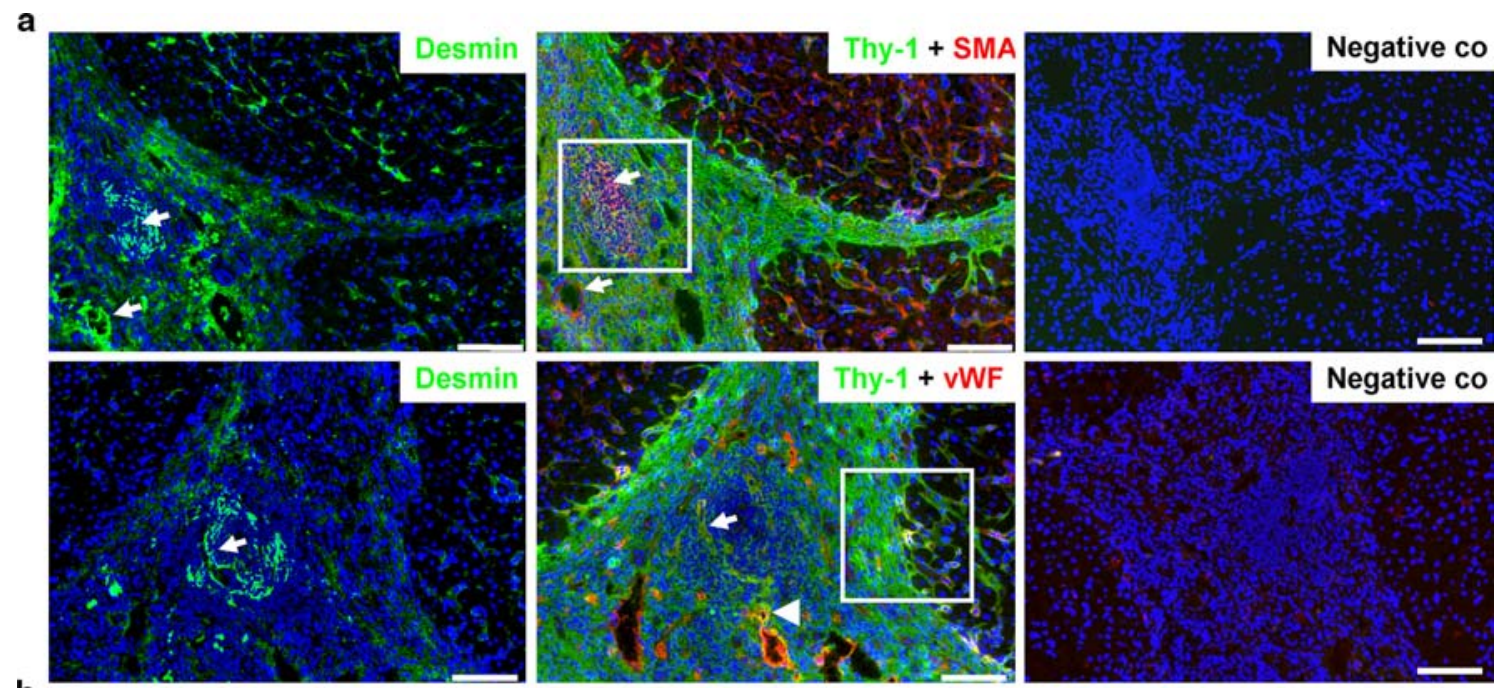

b
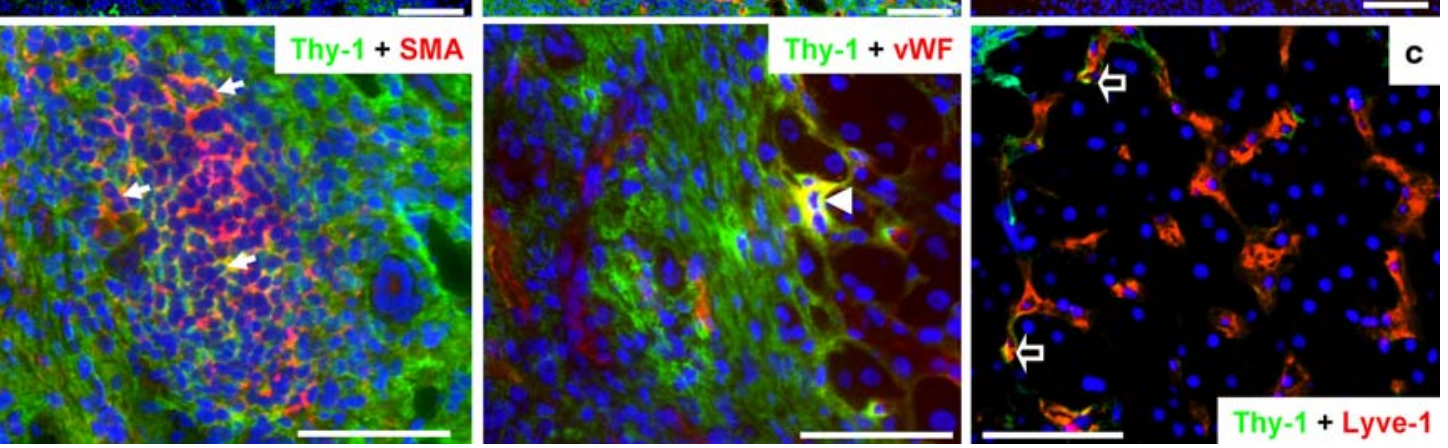

Fig. 7 Analysis of Thy-1, Desmin, SMA, vWF and Lyve-1 in human liver cirrhosis. Immunofluorescent stainings of Thy-1 (green) (a-c), Desmin (green) (a), SMA (red) (a, b) von Willebrand-factor (vWF) (red) (a, b) and LYVE-1 (red) (c) in cirrhotic human liver samples. Boxed areas in $\mathbf{a}$ are displayed at increased magnification in $\mathbf{b}$. Solid arrows indicate co-localization of Thy-1, Desmin and SMA. Arrowheads

broad distribution in the sinusoids including zone 3 . On contrast, Thy-1 is seen only in the sinusoids adjacent to the portal tracts (zone 1) (Fig. 6). Periportal (zone 1) co-localization of Thy-1 and Desmin can be demonstrated readily, but rarely in zone 3 .

Based on the periportal localization of Thy- $1^{+}$cells in normal, injured and regenerating liver, the portal fibroblast cell population is probably the principal source of the periportal Thy-1-expressing cells in liver injury. We presume that, periportal Thy $-1^{+}$myofibroblasts migrate toward zone 3 along the sinusoids under conditions of liver injury. Migration of liver myofibroblasts has been described recently via distinct pathways that signal through rho and p38 MAP kinase (Rege et al. 2006; Tangkijvanich et al. 2003). Interestingly, endogenous or heterologous Thy-1 expression was found to promote focal adhesion and stress fiber formation in isolated lung fibroblasts, characteristic of increased rho-GTPase activity, and inhibited migration (Rege et al. 2006; Barker et al. 2004). Furthermore, also a gene regulatory function was described for Thy-1. Two genes, Fibronectin (FN) and Thrombospondin (TSP-1) indicate the co-localization of Thy-1 and vWF. Empty arrows show colocalization of Thy-1 and Lyve-1. Negative controls were performed by usage of isotype-matching mouse IgG and utilization of rabbit IgG. The blue staining with DAPI represents the nuclei $(\mathbf{a} \times 100$ original magnification; $\mathbf{b}, \mathbf{c} \times 200$ original magnification, bars $100 \mu \mathrm{m})$

involved in cellular differentiation and the regulation of tumor angiogenesis, respectively, were found to be up-regulated upon Thy-1 induction (Abeysinghe et al. 2005). The regulation of Fibronectin-gene-expression might be regulated in a TGF- $\beta 1$ dependent pathway in hepatic stellate cells (Knittel et al. 1996), and in a Thy-1 dependent pathway in portal myofibroblasts.

Although Thy-1 appears to be expressed in periportal fibroblasts and myofibroblasts, the in vivo results of this report demonstrate variability of Thy-1-gene-expression. Previous reports suggest that Thy-1 may act as a cell adhesion molecule. Data assists indicate that Thy- 1 can interact with integrins, but no specific ligand or counterreceptor has been identified. In addition, lipids rafts, in which GPI-anchored proteins, like Thy-1 are embedded, are often the sites of formation of receptor-adhesion complexes (Hudon-David et al. 2007). The fact that Thy- $1^{+}$ and Thy $-1^{-}$lung fibroblasts behave differently suggests that this protein may have a functional role (Koumas et al. 2003). Whether or not Thy-1 is responsible for a specific action in a subpopulation of liver (myo)fibroblasts 
Fig. 8 Analysis of Thy-1, SMA and Desmin in isolated human liver myofibroblasts. Immunofluorescent stainings of SMA (green), Desmin (green) and Thy-1 (green) in isolated and passaged human liver myofibroblasts. The blue staining with DAPI represents the nuclei, $\times 200$ original magnification, bars $100 \mu \mathrm{m}$
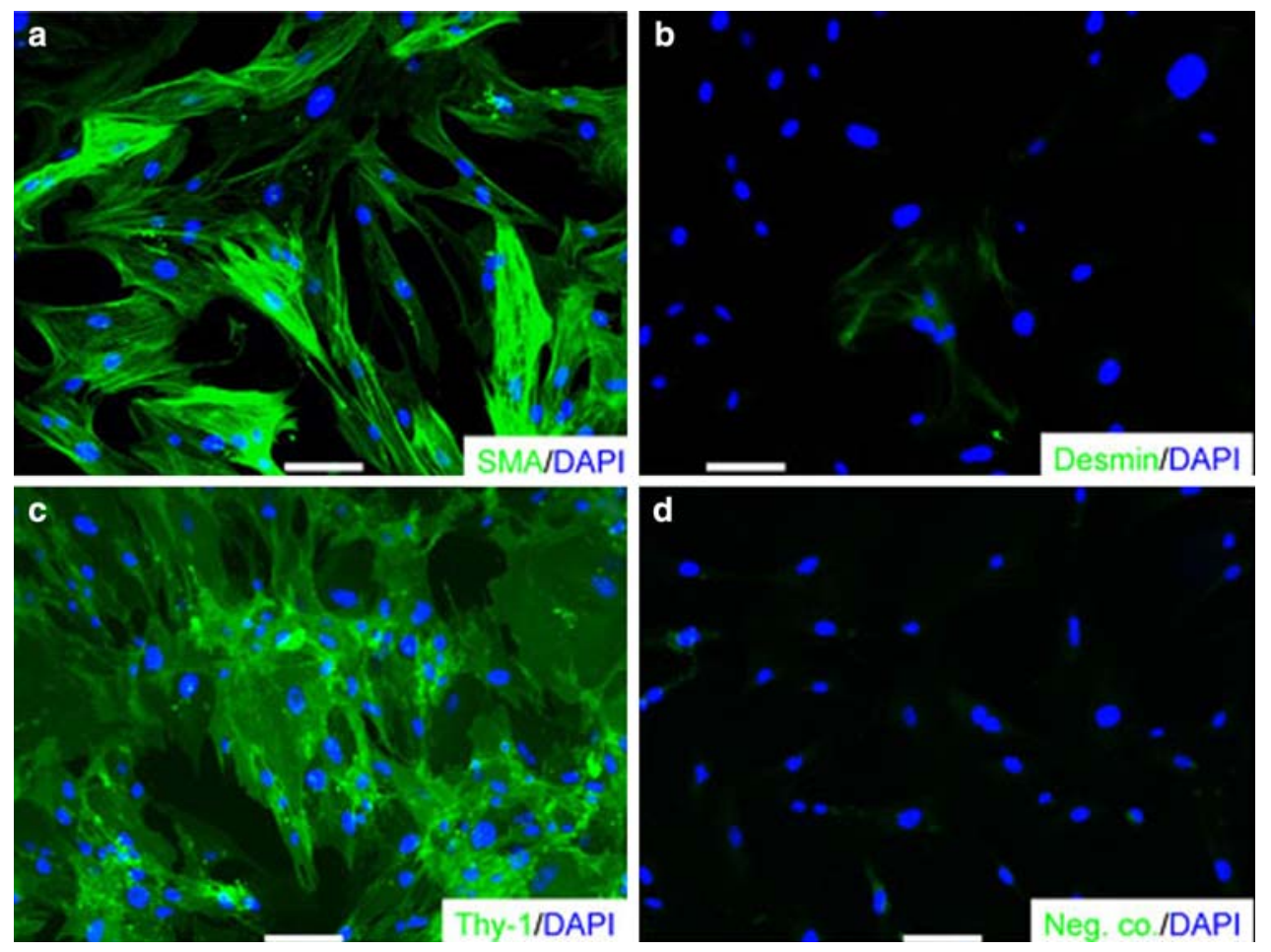

Table 2 Comparison of hepatic stellate cells and liver myofibroblasts, based on previous reports and the findings of this study

\begin{tabular}{|c|c|c|}
\hline & Hepatic stellate cells & Myofibroblasts \\
\hline Definition & Pericytes of the liver sinusoid & Cells responsible for wound healing \\
\hline $\begin{array}{l}\text { Localization in the } \\
\text { normal liver }\end{array}$ & Perisinusoidal & $\begin{array}{l}\text { Periportal, or located around the centrolobular } \\
\text { vein, or in the liver capsule }\end{array}$ \\
\hline $\begin{array}{l}\text { Function in the } \\
\text { normal liver }\end{array}$ & $\begin{array}{l}\text { Vitamin A storage and regulation of retinoid metabolism, } \\
\text { expression of matrix metalloproteinases (MMPs), } \\
\text { matrix turnover (Knittel et al. 1999a) }\end{array}$ & Matrix production, tissue elasticity and resistance \\
\hline Changes in liver injury & $\begin{array}{l}\text { Activation: loss of Vitamin A, SMA expression, } \\
\text { matrix synthesis, expression of tissue } \\
\text { metalloproteinase inhibitors }\end{array}$ & $\begin{array}{l}\text { Activation: due to EDA-containing Fibronectin } \\
\text { (Jarnagin et al. 1994), matrix synthesis, } \\
\text { expression of tissue metalloproteinase inhibitors }\end{array}$ \\
\hline $\begin{array}{l}\text { Localization in the } \\
\text { injured liver }\end{array}$ & Perisinusoidal, and scar-parenchyma interface & Within the scar tissue \\
\hline $\begin{array}{l}\text { Cell culture } \\
\text { characteristics }\end{array}$ & $\begin{array}{l}\text { Spontaneous activation } \\
\text { Increase of cell volume } \\
\text { High DNA and protein synthesis } \\
\text { No cell division } \\
\text { Endoreplication } \\
\text { Spontaneous apoptosis }\end{array}$ & $\begin{array}{l}\text { Increase of cell volume at late passages } \\
\text { High DNA and protein synthesis } \\
\text { Cell division } \\
\text { Inducible apoptosis }\end{array}$ \\
\hline Markers & $\begin{array}{l}\text { Quiescent: Glial Fibrillary Acidic Protein, } \\
\text { weak expression of Desmin, no Thy-1 } \\
\text { Activated: Desmin, SMA, P100, Alpha-2-Macroglobulin, } \\
\text { Reelin (Ogawa et al. 2007) } \\
\text { Synaptophysin (Cassiman and Roskams 2002) } \\
\text { No Thy-1 }\end{array}$ & $\begin{array}{l}\text { Thy-1, SMA, Desmin: only in subpopulations } \\
\text { Special matrix protein expression: Gremlin, } \\
\text { Fibulin-2, Osteopontin (Ogawa et al. 2007) }\end{array}$ \\
\hline $\begin{array}{l}\text { Migration by chronic } \\
\text { liver injury }\end{array}$ & Supposed: from sinusoids toward acinar zones 1 and 3 & From portal scar tissue toward acinar zone 3 \\
\hline Thy-1 expression & Not expressed, not induced & $\begin{array}{l}\text { Constitutive, no upregulation due to treatments } \\
\text { with inflammatory cytokines }\end{array}$ \\
\hline Extrahepatic sources & $\begin{array}{l}\text { According to recent publications is possible from the } \\
\text { bone marrow (Miyata et al. 2008) }\end{array}$ & $\begin{array}{l}\text { Reported from the bone marrow } \\
\text { (Kisseleva et al. 2006) }\end{array}$ \\
\hline
\end{tabular}


remains to be elucidated. The current study suggests that Thy-1 may induce myofibroblast migration along the liver sinusoids.

In conclusion, Thy-1 is a functional marker of liver (myo)fibroblasts in normal, injured and regenerating rat liver, and is located to zone 1 of the liver lobule. Cultureactivated HSC are comparable with perisinusoidal $\mathrm{SMA}^{+}$, Vimentin $^{+}$(Geerts et al. 2001) Desmin, ${ }^{+}$and Thy $1^{-}$cells in vivo, which are located in zone 1 (Table 2). Neither basic expression nor induction of Thy- 1 could be demonstrated in hepatic stellate cells in vivo. Scattered Thy- $1^{+}$sinusoidal cells might be myofibroblasts. Isolated human and rat liver myofibroblasts co-express Thy- 1 and SMA.

Acknowledgments We are grateful to Ms. Ch. Hoffmann, Ms. A. Herbst, Ms. S. Georgi and Mrs R. Köpp for their excellent technical assistance. This work was supported by grants from the Deutsche Forschungsgemeinschaft (SFB 402, projects C6, D3, D4).

Open Access This article is distributed under the terms of the Creative Commons Attribution Noncommercial License which permits any noncommercial use, distribution, and reproduction in any medium, provided the original author(s) and source are credited.

\section{References}

Abeysinghe HR, Li LQ, Guckert NL, Reeder J, Wang N (2005) THY1 induction is associated with up-regulation of fibronectin and thrombospondin-1 in human ovarian cancer. Cancer Genet Cytogenet 161:151-158

Anonymus (1996) Hepatic stellate cell nomenclature. Hepatology 23:193

Barker TH, Grenett HE, MacEwen MW, Tilden SG, Fuller GM, Settleman J, Woods A, Murphy-Ullrich J, Hagood JS (2004) Thy-1 regulates fibroblast focal adhesions, cytoskeletal organization and migration through modulation of p190 RhoGAP and Rho GTPase activity. Exp Cell Res 295:488-496

Blanc JF, Bioulac-Sage P, Balabaud C, Desmouliere A (2005) Investigation of liver fibrosis in clinical practice. Hepatol Res 32:1-8

Cassiman D, Roskams T (2002) Beauty is in the eye of the beholder: emerging concepts and pitfalls in hepatic stellate cell research. J Hepatol 73:527-535

Chirgwin JM, Przybyla AE, MacDonald RJ, Rutter WJ (1979) Isolation of biologically active ribonucleic acid from sources enriched in ribonuclease. Biochemistry 18:5294-5299

Dudas J, Elmaouhoub A, Mansuroglu T et al (2006) Prospero-related homeobox 1 (Prox1) is a stable hepatocyte marker during liver development, injury and regeneration, and is absent from "oval cells". Histochem Cell Biol 126:549-562

Dudas J, Mansuroglu T, Batusic D, Saile B, Ramadori G (2007) Thy1 is an in vivo and in vitro marker of liver myofibroblasts. Cell Tissue Res 329:503-514

Dudas J, Saile B, El-Armouche H, Aprigliano I, Ramadori G (2003) Endoreplication and polyploidy in primary culture of rat hepatic stellate cells. Cell Tissue Res 313:301-311

Geerts A, Eliasson C, Niki T, Wielant A, Vaeyens F, Pekny M (2001) Formation of normal Desmin intermediate filaments in mouse hepatic stellate cells requires vimentin. Hepatology 233:177-188

Guyot C, Lepreux S, Combe C et al (2006) Hepatic fibrosis and cirrhosis; the (myo)fibroblastic cell subpopulations involved. Int J Biochem Cell Biol 38:135-151
Hudon-David F, Bouzeghrane F, Couture P, Thibault G (2007) Thy-1 expression by cardiac fibroblasts: lack of association with myofibroblasts contractile markers. J Mol Cell Cardiol 42:991-1000

Jarnagin WR, Rockey DC, Koteliansky VE, Wang SS, Bissell DM (1994) Expression of variant fibronectins in wound healing: cellular source and biological activity of the EIIIA segment in rat hepatic fibrogenesis. J Cell Biol 127:2037-2048

Johnson SJ, Hines JE, Burt AD (1992) Phenotypic modulation of perisinusoidal cells following acute liver injury: a quantitative analysis. Int J Exp Path 73:765-772

Kisseleva T, Uchinami H, Feirt N, Quintana-Bustamante O, Segovia JC, Schwabe RF, Brenner DA (2006) Bone marrow-derived fibrocytes participate in pathogenesis of liver fibrosis. J Hepatol 45:429-438

Knittel T, Janneck T, Müller L, Fellmer P, Ramadori G (1996) Transforming growth factor beta 1-regulated gene expression of Ito cells. Hepatology 24:352-360

Knittel T, Kobold D, Saile B et al (1999a) Rat liver myofibroblasts and hepatic stellate cells, different cell populations of the fibroblast lineage with fibrogenic potential. Gastroenterology 117:1205-1221

Knittel T, Kobold D, Piscaglia F, Saile B, Neubauer K, Mehde M, Ramadori G (1999b) Localization of liver myofibroblasts and hepatic stellate cells in normal and diseased rat livers: distinct roles of (myo-)fibroblast subpopulations in hepatic tissue repair. Histochem Cell Biol 112:387-401

Koumas L, Smith TJ, Feldon S, Blumberg N, Phipps RP (2003) Thy-1 expression in human fibroblast subsets defines myofibroblastic or lipofibroblastic phenotypes. Am J Path 163:1291-1300

Lee WS, Jain MK, Arkonac BM, Zhang D, Shaw SY, Kashiki S, Maemura K, Lee SL, Hollenberg NK, Lee ME, Haber E (1998) Thy-1, a novel marker for angiogenesis upregulated by inflammatory cytokines. Circ Res 82:845-851

Mansuroglu T, Dudas J, Saile B, Batusic D, Ramadori G (2006) Thy1 expression in human liver cirrhosis and in rat models of liver damage and regeneration. J Hepatol 44:S77 (Abstract)

Mason JC, Yarwood H, Tárnok A, Sugars K, Harrison AA, Robinson PJ, Haskard DO (1996) Human Thy-1 is cytokine-inducible on vascular endothelial cells and is a signaling molecule regulated by protein kinase C. J Immunol 157:874-883

Miyata E, Masuya M, Yoshida S, Nakamura S, Kato K, Sugimoto Y, Shibasaki T, Yamamura K, Ohishi K, Nishii K, Ishikawa F, Shiku H, Katayama N (2008) Hematopoietic origin of hepatic stellate cells in the adult liver. Blood 111:2427-2435

Mouta Carreira C, Nasser SM, di Tomaso E, Padera TP, Boucher Y, Tomarev SI, Jain RK (2001) LYVE-1 is not restricted to the lymph vessels: expression in normal liver blood sinusoids and down-regulation in human liver cancer and cirrhosis. Cancer Res 61:8079-8084

Mueller L, Goumas FA, Affeldt M, Sandtner S, Gehling UM, Brilloff S, Walter J, Karnatz N, Lamszus K, Rogiers X, Broering DC (2007) Stromal fibroblasts in colorectal liver metastases originate from resident fibroblasts and generate an inflammatory microenvironment. Am J Pathol 171:1608-1618

Nakano M, Lieber CS (1982) Ultrastructure of initial stages of perivenular fibrosis in alcohol-fed baboons. Am J Pathol 106:145-155

Neubauer K, Knittel T, Aurisch S, Fellmer P, Ramadori G (1996) Glial fibrillary acidic protein-a cell type specific marker for Ito cells- in vivo and in vitro. J. Hepatol 24:719-730

Neubauer K, Eichhorst ST, Wilfling T, Buchenau M, Xia L, Ramadori G (1998) Sinusoidal intercellular adhesion molecule-1 up-regulation precedes the accumulation of leukocyte function antigen-1positive cells and tissue necrosis in a model of carbontetrachloride-induced acute rat liver injury. Lab Invest 78:185-194

Novosyadlyy R, Tron K, Dudas J, Ramadori G, Scharf JG (2004) Expression and regulation of the insulin-like growth factor axis components in rat liver myofibroblasts. J Cell Physiol 199:388-398 
Ogawa T, Tateno C, Asahina K, Fujii H, Kawada N, Obara M, Yoshizato K (2007) Identification of vitamin A-free cells in a stellate cell-enriched fraction of normal rat liver as myofibroblasts. Histochem Cell Biol 127:161-174

Pei Y, Sherry DM, McDermott AM (2004) Thy-1 distinguishes human corneal fibroblasts and myofibroblasts from keratocytes. Exp Eye Res 79:705-712

Raddatz D, Bockemuhl M, Ramadori G (2005) Quantitative measurement of cytokine mRNA in inflammatory bowel disease, relation to clinical and endoscopic activity and outcome. Eur J Gastroenterol Hepatol 17:547-557

Ramadori G, Veit T, Schwögler S et al (1990) Expression of the gene of the a-smooth muscle-actin isoform in rat liver and in fat storing (Ito) cells. Virchow's Archive B Cell Pathol 59:349-357

Ramadori G, Saile B (2002) Mesenchymal cells in the liver-one cell type or two? Liver 22:283-294

Ramadori G, Saile B (2004) Portal tract fibrogenesis in the liver. Lab Invest 84:153-159

Rege TA, Pallero MA, Gomez C, Grenett HE, Murphy-Ullrich JE, Hagood JS (2006) Thy-1, via its GPI anchor, modulates Src family kinase and focal adhesion kinase phosphorylation and subcellular localization, and fibroblast migration, in response to thrombospondin-1/hep I. Exp Cell Res 312:3752-3767

Reif AE, Allen JM (1964) The akr thymic antigen and its distribution in leukemias and nervous tissues. J Exp Med 120:413-433

Saile B, Eisenbach C, Dudas J, El-Armouche H, Ramadori G (2004) Interferon-gamma acts proapoptotic on hepatic stellate cells (HSC) and abrogates the antiapoptotic effect of interferon-alpha by an HSP70-dependant pathway. Eur J Cell Biol 83:469-476
Saile B, Knittel T, Matthes N, Schott P, Ramadori G (1997) CD95/ CD95L-mediated apoptosis of the hepatic stellate cell. A mechanism terminating uncontrolled hepatic stellate cell proliferation during hepatic tissue repair. Am J Pathol 151:1265-1272

Saile B, Matthes N, Neubauer K et al (2002) Rat liver myofibroblasts and hepatic stellate cells differ in CD95-mediated apoptosis and response to TNF-alpha. Am J Physiol Gastrointest Liver Physiol 283:G435-G444

Schirmacher P, Geerts A, Pietrangelo A, Dienes HP, Rogler CE (1992) Hepatocyte growth factor/hepatopoietin A is expressed in fatstoring cells from rat liver but not myofibroblast-like cells derived from fat-storing cells. Hepatology 15:5-11

Sheikh N, Batusic DS, Dudas J, Tron K, Neubauer K, Saile B, Ramadori G (2006) Hepcidin and hemojuvelin gene expression in rat liver damage: in vivo and in vitro studies. Am J Physiol Gastrointest Liver Physiol 291:G482-G490

Tangkijvanich P, Melton AC, Santiskulvong C, Yee HF Jr (2003) Rho and p38 MAP kinase signaling pathways mediate LPA-stimulated hepatic myofibroblast migration. J Biomed Sci 10:352-358

Tiggelman AM, Boers W, Linthorst C, Brand HS, Sala M, Chamuleau RA (1995) Interleukin-6 production by human liver (myo)fibroblasts in culture. Evidence for a regulatory role of LPS, IL-1 beta and TNF alpha. J Hepatol 23:295-306

Wirz W, Antoine M, Tag CG, Gressner AM, Korff T, Hellerbrand C, Kiefer P (2008) Hepatic stellate cells display a functional vascular smooth muscle cell phenotype in a three-dimensional co-culture model with endothelial cells. Differentiation (Epub ahead of print: 2008 January 2) 